EDUKACJA MIĘDZYKULTUROWA

\title{
Działalność EuroInstytutu \\ Polsko-Czesko-Słowackiego w zakresie współpracy transgranicznej i międzykulturowej
}

Streszczenie: W 2009 roku Stowarzyszenie Rozwoju i Współpracy Regionalnej "Olza” wraz z Institutem EuroSchola z Trzyńca powołało na pograniczu polsko-czesko-słowackim pierwszy w Europie Środkowo-Wschodniej EuroInstytutut do spraw współpracy transgranicznej. Głównymi obszarami działalności EuroInstytutu Polsko-Czesko-Słowackiego są: działalność szkoleniowo-doradcza, działalność koncepcyjna i badawcza oraz działalność edukacyjna i wydawnicza. EuroInstytut współpracuje z placówkami naukowymi i instytucjami doradczo-szkoleniowymi z kraju i zagranicy. Wydaje serię „TRANSCARPATHICA” i organizuje konferencje o wymiarze międzynarodowym, poświęcone relacjom sąsiedzkim łączącym Polaków, Czechów i Słowaków.

Słowa kluczowe: EuroInstytut Polsko-Czesko-Słowacki, współpraca transgraniczna i międzykulturowa, działalność badawcza i naukowa, szkolenia.

\section{Wprowadzenie}

Globalizacja, transformacja i integracja, widoczne w wielu dziedzinach życia społecznego, gospodarczego, kulturowego i politycznego XXI wieku, wskazują na ważny problem, jakim jest współpraca transgraniczna. Współpraca ta dotyczy wielu aspektów, między innymi propagowania edukacji regionalnej i międzykulturowej, a możliwości wdrażania tego typu edukacji są ściśle związane z modelami i strategiami w zakresie polityki społecznej ${ }^{1}$.

Współpraca transgraniczna umożliwia znoszenie barier wynikających z istnienia granic państwowych i tworzenie „pomostów” między sąsiadujący-

1 Z. Jasiński: Przemiany w polityce oświatowej i spotecznej w kontekście edukacji międzykulturowej. W: T. Lewowicki i E. Ogrodzka-Mazur (red.): Z teorii i praktyki edukacji międzykulturowej. Cieszyn - Warszawa 2006, Uniwersytet Śląski, Wyższa Szkoła Pedagogiczna ZNP w Warszawie, s. 32. 
mi ze sobą krajami². Stwarza ona także warunki do ożywiania życia lokalnej i regionalnej społeczności, zarówno w sferze materialnej - w postaci rozwoju gospodarczego, jak i niematerialnej - polegające na zmianie postawy wobec partnera, która była wcześniej nieufna lub nawet wroga. Za pośrednictwem współpracy transgranicznej dokonują się procesy uspołeczniania stosunków zewnętrznych państwa poprzez uczenie się tolerancji względem odmienności kulturowej, etnicznej i religijnej sąsiada ${ }^{3}$. Współpraca transgraniczna pełni też istotną rolę $\mathrm{w}$ przeobrażaniu stosunków międzynarodowych, minimalizując lub eliminując antagonizmy i resentymenty, oraz przyczynia się do czerpania korzyści ze wzajemnej kooperacji instytucji znajdujących się po obu stronach granicy ${ }^{4}$.

Uzasadnienie celowości prowadzenia współpracy transgranicznej wyraża najpełniej preambuła Europejskiej Karty Regionów Granicznych i Transgranicznych, w której podkreślono między innymi, że „[...] współpraca transgraniczna pomaga w łagodzeniu niekorzystnych skutków istnienia granic, będących „bliznami historii”, a także w przezwyciężaniu skutków położenia terenów przygranicznych na narodowych obrzeżach państw oraz służy poprawie warunków życiowych osiadłej tam ludności ${ }^{5}$.

\section{Założenia metodologiczne}

Na pograniczu polsko-czeskim realizowana jest współpraca, która łączy zarówno samorządy, społeczności lokalne, jak i wiele instytucji naukowych. Praktycz-

2 Euroregiony na granicach Polski 2007. Wrocław 2007, s. 14; Studium wykonalności EuroInstytutu. Etap 1, Raportz warsztatów poświęconych pracom nad stworzeniem międzynarodowego ośrodka doradczo-szkoleniowego - Euroinstytutu w Euroregionie Ślask Cieszyński, autorzy: M. Olszewski / Stowarzyszenie Rozwoju i Współpracy Regionalnej „Olza” w Cieszynie, B. Kasperek / Stowarzyszenie Rozwoju i Współpracy Regionalnej „Olza” w Cieszynie, A. Olszewska / Stowarzyszenie Rozwoju i Współpracy Regionalnej „Olza” w Cieszynie, A. Lewczuk / Biuro Współpracy Dolnego Renu i Województwa Śląskiego Anne Thevenet / Euro-Institut Kehl Strasbourg, Hynek Böhm / Institut EuroSchola v Třinci, Cieszyn 2010, s. 4.

3 Studium wykonalności EuroInstytutu. Etap 1, Raport $z$ warsztatów poświęconych pracom nad stworzeniem międzynarodowego ośrodka doradczo-szkoleniowego - Euroinstytutu w Euroregionie Śląsk Cieszyński..., s. 4.

4 Tamże, s. 4.

5 Europejska Karta Regionów Granicznych i Transgranicznych - nowelizacja SERG, Gronau 2004, s. 3. 
nym wymiarem tej współpracy są realizowane projekty i partnerskie relacje, które stale pobudzają nowe pomysły i inicjatywy zbliżające mieszkańców pogranicza $^{6}$. Współpracą regionalną i międzykulturową zajmuje się wiele instytucji, a jedną z nich jest inicjatywa EuroInstytutu Polsko-Czesko-Słowackiego.

Celem przeprowadzonych badań jest przybliżenie różnych form działalności EuroInstytutu w latach 2009-2015. Realizowane poczynania badawcze mają charakter pedagogiczny, a prezentowany artykuł jest szkicem monograficznym. Główny problem badawczy został sformułowany w postaci pytania: Jakie działania podejmuje EuroInstytut Polsko-Czesko-Słowacki w zakresie współpracy transgranicznej i międzykulturowej? Przedmiotem analiz są różne formy aktywności EuroInstytutu. Podstawę zbierania danych w badaniach własnych stanowiły analiza dokumentów oraz wywiad jawny ${ }^{7}$. Wybór takich metod i technik był uzasadniony metodologicznie ze względu na sformułowany problem badawczy.

Analizie poddano: statut i sprawozdania Stowarzyszenia Rozwoju i Współpracy Regionalnej „Olza”, koncepcje działalności EuroInstytutu, opracowania, dokumenty wspólnotowe, raport z prowadzonych warsztatów, studium wykonalności EuroInstytutu i publikacje wydawane przez wspomniane stowarzyszenie. Analiza dokumentów pozwoliła określić ich wartość poznawczą i wskazać na fakty odnoszące się do podjętej tematyki zawartej w tytule artykułu.

Postępowanie badawcze koncentrowało się wokół czterech głównych zagadnień:

- genezy EuroInstytutu,

- aktywności edukacyjno-naukowej,

- współpracy z ośrodkami naukowymi,

- organizowanych projektów.

Struktura niniejszego tekstu przybliża wzmiankowane zagadnienia, a ostatnia sekcja artykułu jest podsumowaniem przeprowadzonych badań.

\section{Geneza EuroInstytutu}

Pomysł utworzenia EuroInstytutu Polsko-Czesko-Słowackiego został zaczerpnięty z pogranicza francusko-niemieckiego, gdzie w 1993 roku w mie-

6 B. Kasperek (red.): Euroregiony pogranicza polsko-czeskiego. Cieszyn 2014, s. 6.

7 Wywiad z Bogdanem Kasperkiem, dyrektorem Biura Stowarzyszenia Rozwoju i Współpracy Regionalnej „Olza”. 
ście Kehl powstał Instytut ds. współpracy transgranicznej - Euro-Institut. Jest to dwunarodowa, neutralna platforma współpracy, posiadająca dwujęzyczny i dwukulturowy zespół pracowników. Euro-Institut odpowiada na potrzeby różnych instytucji i mieszkańców z pogranicza francusko-niemieckiego poprzez dostarczanie informacji, wiedzy, metod i narzędzi pracy, prowadzenie szkoleń i kształcenie w zakresie współpracy transgranicznej. Pomaga podmiotom z obu części pogranicza, tj. Francji i Niemiec, w rozwiązywaniu problemów wynikających z różnych systemów polityczno-administracyjnych, strukturalnych, w minimalizowaniu wszelkiego rodzaju barier administracyjnych, społecznych, kulturowych oraz w prowadzeniu działań na rzecz współpracy ponad granicami ${ }^{8}$.

Należy dodać, że współpraca lokalnych i regionalnych społeczności wykraczająca poza granice państwowe narodziła się w Europie Zachodniej w połowie XX wieku. Jej prekursorami były regiony z pogranicza niemiecko-francuskiego, holendersko-niemieckiego i norwesko-szwedzkofińskiego. Współpracę transgraniczną podjęto również w Europie Środkowej, co wiązało się bezpośrednio z zaistniałymi przemianami politycznymi i rozwojem demokracji ${ }^{9}$.

Współpraca transgraniczna regulowana jest w Polsce poprzez cztery normy prawa międzynarodowego, do którego należą:

- Europejska Konwencja Ramowa o Współpracy Transgranicznej Między Wspólnotami i Władzami Terytorialnymi (tzw. Konwencja Madrycka),

- Europejska Karta Regionów Granicznych i Transgranicznych,

- Europejska Karta Samorządu Terytorialnego,

- Europejska Karta Samorządu Regionalnego.

Pierwsza z regulacji została przyjęta przez Radę Europy 21 maja 1980 roku ${ }^{10}$. Proces euroregionalizacji zapoczątkował w Polsce Euroregion Nysa ${ }^{11}$.

8 EuroInstytut Polsko-Czesko-Stowacki, bmirw.

9 B. Kasperek (red.): Euroregiony pogranicza polsko-czeskiego. cyt. wyd., s. 11-13 .

10 S. Sitek: Wspótpraca transgraniczna w ramach euroregionów na pograniczu polsko-czeskim. W: B. Kasperek (red.): Euroregiony pogranicza polsko-czeskiego. cyt. wyd., s. 8-13.

11 Euroregion Nysa utworzony został na przełomie lat 1990/1991. Euroregion obejmuje trzy obszary przygraniczne położone w Środkowej Europie, u styku granic Polski, Czech i Niemiec. M. Zdulski: Wspótpraca transgraniczna w Euroregionie Neisse-Nisa-Nysa. W: B. Kasperek (red.): Euroregiony pogranicza polsko-czeskiego. cyt. wyd., s. 66-79; Studium wykonalności EuroInstytutu. Etap 1, Raport z warsztatów po- 
W stosunkowo krótkim okresie czasu na wszystkich polskich granicach powstało i prowadzi obecnie działalność 17 euroregionów ${ }^{12}$.

Jednym z kluczowych ogniw współpracy transgranicznej oprócz struktur euroregionalnych są profilowane instytucje powołane do realizacji ściśle określonych zadań. Podmioty te, funkcjonując w przestrzeni publicznej, uzupełniają aktywności prowadzone przez euroregiony, przyczyniając się jednocześnie do integracji społeczeństw zamieszkujących obie strony granicy ${ }^{13}$.

Pierwsze działania dotyczące utworzenia EuroInstytutu Polsko-Czesko-Słowackiego zostały zainicjowane w roku 2009 przez Stowarzyszenia Rozwoju i Współpracy Regionalnej „Olza” w Cieszynie przy współudziale Institutu EuroSchola z Trzyńca. Zorganizowano międzynarodowe seminarium z udziałem przedstawicieli Euro-Institutu Kehl/Strasbourg, Parlamentu Europejskiego, Śląskiego Urzędu Wojewódzkiego, Urzędu Marszałkowskiego Województwa Śląskiego, Biura Współpracy Dolnego Renu i Województwa Śląskiego, Institutu EuroSchola, wspomnianego Stowarzyszenia „Olza”, euroregionalnych grup roboczych z polskiej strony Euroregionu Śląsk Cieszyński oraz ekspertów z Republiki Czeskiej. Efektem seminarium było przygotowanie dokumentu koncepcyjnego, zawierającego wstępne założenia dotyczące powołania i funkcjonowania przyszłego EuroInstytutu ${ }^{14}$. Koncepcja została podzielona na dwa etapy: projektowy i instytucjonalny. Kontynuację aktywności zapoczątkowanych na międzynarodowym seminarium stanowił projekt „Studium Wykonalności EuroInstytutu PL-CZ (etap pierwszy) - organizacja międzynarodowych warsztatów". W Studium określono etapy tworzenia organizacji od momentu identyfikacji przeszkód i potrzeb związanych ze współpracą transgraniczną na pograniczu Polski-Czech i Słowacji. Główne działania koncentrowały się na przygotowaniu czterech warsztatów adresowanych do różnych grup uczestników. W pierwszym warsztacie uczestniczyli przedstawiciele euroregionalnych grup roboczych z Euroregionu Śląsk

święconych pracom nad stworzeniem międzynarodowego ośrodka doradczo-szkoleniowego - Euroinstytutu w Euroregionie Ślask Cieszyński..., s. 4.

12 Tamże. Pierwsza umowa o współpracy regionalnej pochodzi z roku 1994 i zawarta została pomiędzy Związkiem Komunalnym Ziemi Cieszyńskiej ze strony polskiej oraz Radą Regionalną z Trzyńca i Stowarzyszeniem Miast i Gmin Okresu Karwina ze strony czeskiej.

13 M. Olszewski: Koncepcja powstania międzynarodowego ośrodka doradczo-szkoleniowego EuroInstytutu PL-Cz, Stowarzyszenie Rozwoju $i$ Wspótpracy Regionalnej „Olza”, Cieszyn 2009, s. 4.

14 Opracowano na podstawie dokumentów EuroInstytutu. 
Cieszyński, w drugim przedstawiciele polskich i czeskich samorządów tworzących Euroregion. W trzecim warsztacie brali udział przedstawiciele organizacji z pogranicza francusko-niemieckiego, natomiast w czwartym przedstawiciele polskich i czeskich instytucji doradczo-szkoleniowych ośrodków naukowych i liderów branżowych. Należy podkreślić, że EuroInstytut powstał jako odpowiedź na problemy i potrzeby instytucji związanych ze współpracą transgraniczną Polski, Czech i Słowacji ${ }^{15}$.

\section{Struktura EuroInstytutu Polsko-Czesko-Słowackiego}

Aktualnie EuroInstytut Polsko-Czesko-Słowacki jest siecią instytucji partnerskich, którą tworzą następujące organizacje:

- Stowarzyszenie Rozwoju i Współpracy Regionalnej „Olza” - polska strona Euroregionu Śląsk Cieszyński (Cieszyn),

- Institut EuroSchola (Třinec),

- Regionální sdružení územní spolupráce Těšínského Slezska - czeska strona Euroregionu Śląsk Cieszyński (Český Těšín),

- Regionální rada rozvoje a spolupráce (Třinec),

- Stowarzyszenie Gmin Dorzecza Górnej Odry - polska strona Euroregionu Silesia (Racibórz),

- Euroregion Silesia CZ (Opava),

- Pedagogické centrum pro polské národnostní školství Český Těšín,

- Uniwersytet Śląski w Katowicach - Wydział Etnologii i Nauk o Edukacji (Cieszyn) oraz Wydział Nauk o Ziemi (Katowice),

- Združenie obcí Mikroregión Kysucký triangel (Čadca),

- KERIC $\left(\check{C ̆}_{\text {adca }}\right)^{16}$.

Instytucje te współpracują ze sobą przy organizacji szkoleń i przygotowaniu publikacji.

Aby nadać charakter formalny, podnieść rangę i zapewnić odpowiedni poziom budowania sieci partnerów EuroInstytutu Polsko-Czesko-Słowackiego, powołano Radę Programową, której przedstawicielami są osoby reprezen-

15 M. Olszewski: Koncepcja powstania międzynarodowego ośrodka doradczo-szkoleniowego EuroInstytut PL-CZ, Cieszyn 2009; Studium Wykonalności EuroInstytutu - Etap I, Cieszyn 2010, s. 10; Dokumentacja EuroInstytutu.

16 Oferta szkoleniowa EuroInstytutu Polsko-Czesko-Stowackiego Oferta, brimw, s. 4; wywiad z Bogdanem Kasperkiem, dyrektorem Biura Stowarzyszenia Rozwoju i Współpracy Regionalnej „Olza”. 
tujące samorządy, euroregiony, uczelnie wyższe, instytucje szkoleniowo-doradcze i badawcze oraz organizacje pozarządowe z Polski, Czech i Słowacji.

\section{Główne zadania i formy działalności EuroInstytutu}

Do głównych zadań należą:

- prowadzenie działalności w obszarze granicznym,

- posiadanie partnerów z obu stron granicy,

- przyczynianie się do realizacji działań na rzecz interesu publicznego,

- wspieranie współpracy transgranicznej poprzez organizację szkoleń i prowadzenie badań,

- ukierunkowanie działalności na rzecz instytucji administracji publicznej lub innych podmiotów przyczyniających się do realizacji interesu publicznego,

- dysponowanie wielonarodowym i wielokulturowym zespołem ludzi posługującym się językami stosowanymi na pograniczu,

- respektowanie języków używanych przez autorów współpracy transgranicznej i umożliwienie posługiwania się nimi w realizowanych działaniach,

- zachęcanie do współpracy struktur mających odmienną logikę pracy $\mathrm{z}$ uwzględnieniem międzykulturowości,

- rozwijanie metod i narzędzi do prowadzenia szkoleń transgranicznych dostosowanych do różnic kulturowych i potrzeb pogranicza ${ }^{17}$.

Głównymi obszarami działalności EuroInstytu są:

- działalność doradczo-szkoleniowa ogólna i specjalistyczna,

- działalność koncepcyjna i badawcza,

- działalność edukacyjna i wydawnicza ${ }^{18}$.

\section{Działalność doradczo-szkoleniowa}

EuroInstytut prowadzi transgraniczne szkolenia umożliwiające nabycie kompetencji niezbędnych do współpracy z partnerami z drugiej strony granicy. Szkolenia w zależności od potrzeb grup docelowych prowadzone są w dwóch

17 Studium wykonalności EuroInstytutu. Etap 1, Raport z warsztatów poświęconych pracom nad stworzeniem międzynarodowego ośrodka doradczo-szkoleniowego - Euroinstytutu w Euroregionie Śląsk Cieszyński..., s. 18.

18 Tamże, s.22. 
lub trzech językach (polskim, czeskim, słowackim). Organizowane są dwa rodzaje szkoleń: szkolenia interaktywne oraz specjalistyczne.

Szkolenia interaktywne ukierunkowane są na doskonalenie kompetencji miękkich, takich jak: efektywna komunikacja z partnerem, praca w zespole międzynarodowym, twórcze i pozytywne myślenie w sytuacjach „bez wyjścia", dostosowanie się do zmian w transgranicznym środowisku pracy, dialog międzykulturowy itp.

Szkolenia specjalistyczne ukierunkowane są na zdobywanie fachowej wiedzy i umiejętności z zakresu konkretnych dziedzin, takich jak: prawo i administracja, edukacja, zarządzanie kryzysowe, ochrona środowiska itp. Celem tego typu szkoleń jest przedstawienie danej problematyki w ujęciu transgranicznym, porównanie różnych systemów administracyjnych, sposobów zarządzania, zakresu kompetencji w odniesieniu do poszczególnych krajów, dobrych praktyk stosowanych w kraju sąsiada, a także wymiana doświadczeń. Szkolenia te umożliwiają również nawiązanie współpracy w konkretnej dziedzinie wiedzy pomiędzy instytucjami poszukującymi partnera z drugiej strony granicy. W obu typach szkoleń stosuje się odpowiednie metody i narzędzia pracy, które transferowane są z innych europejskich regionów granicznych i dostosowane do potrzeb pogranicza polsko-czesko-słowackiego. Organizatorzy szkoleń korzystają między innymi z doświadczeń francusko-niemieckich, francusko-hiszpańskich, austriacko-słoweńsko-włoskich i irlandzkich.

Tabela 1. Szkolenia stałe prowadzone przez EuroInstytut Polsko-Czesko-Słowacki

\begin{tabular}{|c|c|}
\hline Rodzaj szkolenia & \multicolumn{1}{c|}{ Nazwa szkolenia } \\
\hline \multirow{3}{*}{ Szkolenia interaktywne } & - Myślenie koncepcyjne jako narzędzie współpracy transgranicznej. \\
& $\begin{array}{l}\text { - Zarządzanie zasobami ludzkimi w międzynarodowym środowisku } \\
\text { pracy. } \\
\text { - Efektywna komunikacja w kontekście międzykulturowym }\end{array}$ \\
\hline Szkolenia specjalistyczne & - Słownictwo z zakresu współpracy transgranicznej w językach polskim, \\
& czeskim i słowackim. \\
& - Dobre praktyki w realizacji działań transgranicznych. \\
& - Pozyskiwanie funduszy na realizację projektów z partnerami \\
& zagranicznymi na przykładzie współpracy z młodzieżą. \\
& - Szkolenia dostosowane do indywidualnych potrzeb grup. \\
\hline
\end{tabular}

Źródło: Opracowano na podstawie dokumentacji EuroInstytutu Polsko-Czesko-Słowackiego.

W ramach działalności szkoleniowo-doradczej organizowane są spotkania i konsultacje z zakresu pozyskiwania funduszy oraz zarządzania projektami transgranicznymi, a także wizyty studyjne dla grup zorganizowanych od- 
wiedzających pogranicze. Szkolenia prowadzone są w Cieszynie i Trzyńcu z wykorzystaniem wysokiej klasy aparatury do tłumaczeń symultanicznych ${ }^{19}$.

W latach 2011-2015 przeprowadzono trzy szkolenia interaktywne i cztery specjalistyczne (por. tabela 1). Na uwagę zasługuje szkolenie interaktywne pt. „Efektywna komunikacja w kontekście międzykulturowym”. Celem szkolenia było wsparcie rozwoju kompetencji komunikacyjnych uczestników niezbędnych do skutecznej współpracy w wymiarze transgranicznym, budowanie relacji z partnerem, przekraczanie stereotypów, umiejętne interpretowanie zjawisk kulturowych. Szkolenie przeznaczone było dla osób podejmujących współpracę z partnerami zagranicznymi, zwłaszcza z drugiej strony granicy, narażonych na występowanie sytuacji konfliktowych i dążących do ich zminimalizowania w celu poprawy jakości prowadzonej współpracy. Grupą docelową byli pracownicy uczelni wyższych oraz studenci Uniwersytetu Śląskiego w Katowicach ${ }^{20}$.

Jak podkreśla B. Kasperek, „staramy się, aby EuroInstytut Polsko-Czesko-Słowacki spełniał oczekiwania odbiorców, do których adresujemy nasze działania. Proponujemy dodatkowo, oprócz standardowej oferty szkoleniowej, warsztaty dostosowane do indywidualnych potrzeb grup w obszarach, które interesują autorów pogranicza w szczególny sposób. Jesteśmy gotowi przygotować szkolenia na zamówienie w wielu tematach, między innymi: Edukacja regionalna w ujęciu transgranicznym, Kultura - realia w Polsce, Czechach i na Słowacji, Szkolnictwo wyższe i badania - spojrzenie przekrojowe polsko-czesko-słowackie, Współpraca transgraniczna w dziedzinie ochrony zdrowia i pomocy społecznej”21.

\section{Współpraca z placówkami naukowymi i instytucjami doradczo-szkoleniowymi z kraju i zagranicy}

EuroInstytut od 2011 roku uczestniczy w pracach elitarnej sieci TEIN (Transfrontier Euro-Institut Network), która zrzesza podmioty z różnych krajów specjalizujące się w kształceniu, szkoleniach i doradztwie transgranicznym.

19 Wywiad z Bogdanem Kasperkiem, dyrektorem Biura Stowarzyszenia Rozwoju i Współpracy Regionalnej „Olza”.

20 http://www.euro-in.org/ (7.01.2016); wywiad z Bogdanem Kasperkiem, dyrektorem Biura Stowarzyszenia Rozwoju i Współpracy Regionalnej „Olza”.

21 Dokumenty EuroInstytutu; wywiad przeprowadzony z Bogdanem Kasperkiem, dyrektorem Biura Stowarzyszenia Rozwoju i Współpracy Regionalnej „Olza”. 
Są nimi:

- Associazione Forser Friuli Venezia Giulia - Formazione e servizi per la Pubblica amministrazione (Włochy),

- EVTZ-Kompetenzzentrum Viadrina Center B/Orders in Motion Europa-Universität Viadrina (Niemcy),

- Fachhochschule Kärnten (Austria),

- Institut pour la coopération transfrontalière - Euro-Institut (Niemcy),

- Institut EuroSchola (Czechy),

- Stowarzyszenie Rozwoju i Współpracy Regionalnej „Olza” (Polska),

- The Centre for Cross Border Studies (Irlandia Północna),

- Université d'Artois - Institut des frontières et des discontinuités (Francja),

- Universitat de Girona (Hiszpania),

- Université de Perpignan Via Domitia - ICRESS Institut Catalan de Recherche en Sciences Sociales (Francja),

- Université de Strasbourg - Institut d'Études Politiques de Strasbourg (Francja),

- Université Savoie Mont Blanc (Francja),

- Univerze v Ljubljani Fakulteta za upravo (Słowenia),

- Arbeitsgemeinschaft Europäischer Grenzregionen (Niemcy) - członek stowarzyszony z siecią,

- Mission Opérationnelle Transfrontalière (Francja) - członek stowarzyszony z sieciąa ${ }^{22}$.

Do zadań związanych ze współpracą z wymienionymi ośrodkami naukowymi, należy również uczestnictwo w pracach naukowych, opracowywanie wyników badań i analiz, a także przygotowywanie dokumentów o charakterze planistycznym i strategicznym na rzecz współpracy transgranicznej. Przykładem współpracy była realizacja wspólnego partnerskiego projektu pn. „EURO-IN”, który stanowił jeden z etapów tworzenia międzynarodowego ośrodka ds. kształcenia transgranicznego - EuroInstytutu Polsko-Czesko-Słowackiego. W ramach projektu prowadzone były trzy grupy działań wpisujące się w działalność: analityczno-koncepcyjną, szkoleniowo-doradczą oraz informacyjno-promocyjną.

Działania szkoleniowo-doradcze obejmowały serię pilotażowych szkoleń, spotkań i forów transgranicznych. Nowatorskie podejście do prowadzenia szkoleń polegało na zaprezentowaniu tematu w ujęciu transgranicznym (polsko-czesko-słowackim). Spotkania służyły pogłębianiu współpracy instytucji tworzących partnerstwo euroinstytutowe poprzez ustalanie potrzeb

22 EuroInstytut Polsko-Czesko-Stowacki, brw. s. 11-12. 
związanych z problematyką transgraniczną Polski, Czech i Słowacji oraz wypracowanie wspólnych ram działania. Transgraniczne fora to $\mathrm{z}$ kolei forma wymiany dobrych praktyk oraz promocji problematyki transgranicznej i jej znaczenia z punktu widzenia rozwoju regionu.

Trzecia grupa działań skierowana była na promocję projektu i działalności EuroInstytutu Polsko-Czesko-Słowackiego za pośrednictwem strony internetowej, broszur informacyjnych, kampanii promocyjnych, rollbannerów, systemu identyfikacji wizualnej oraz międzynarodowej konferencji w Katowicach. Działania zostały zrealizowane na wysokim poziomie organizacyjnym dzięki zakupionemu w ramach projektu sprzętowi do tłumaczeń symultanicznych ${ }^{23}$.

W ramach współpracy z instytucjami EuroInstytut w latach 2009-2015 zrealizował wiele projektów, które przedstawione są w tabeli 2 .

Tabela 2. Projekty realizowane przez EuroInstytut Polsko-Czesko-Słowacki

\begin{tabular}{|l|c|l|}
\hline \multicolumn{1}{|c|}{ Tytuł projektu } & Data & \multicolumn{1}{|c|}{ Źródło finansowania } \\
\hline $\begin{array}{l}\text { „EURO-IN - Budowanie i testowanie partnerstwa ukie- } \\
\text { runkowanego na problematykę transgraniczną w ra- } \\
\text { mach prac nad tworzeniem międzynarodowego ośrodka } \\
\text { ds. kształcenia transgranicznego - EuroInstytutu” }\end{array}$ & $2014-2015$ & $\begin{array}{l}\text { Program Operacyjny Współ- } \\
\text { pracy Transgranicznej Repu- } \\
\text { blika Czeska - Rzeczpospolita } \\
\text { Polska }\end{array}$ \\
\hline $\begin{array}{l}\text { „Międzynarodowe seminarium pn.: Koncepcja powstania } \\
\text { EuroInstytutu PL-CZ” }\end{array}$ & 2009 & $\begin{array}{l}\text { Samorząd Województwa Ślą- } \\
\text { skiego }\end{array}$ \\
\hline $\begin{array}{l}\text { „Studium Wykonalności EuroInstytutu PL-CZ (etap } \\
\text { pierwszy) - organizacja międzynarodowych warsztatów” }\end{array}$ & 2010 & $\begin{array}{l}\text { Samorząd Województwa Ślą- } \\
\text { skiego }\end{array}$ \\
\hline $\begin{array}{l}\text { „Studium Wykonalności EuroInstytutu PL-CZ-SK (etap } \\
\text { drugi)” }\end{array}$ & 2011 & $\begin{array}{l}\text { Samorząd Województwa Ślą- } \\
\text { skiego }\end{array}$ \\
\hline $\begin{array}{l}\text { „PAT-TEIN" } \\
\text { „EuroInstytut Polsko-Czesko-Słowacki - aktywizacja } \\
\text { działalności wydawniczej” }\end{array}$ & 2014 & $\begin{array}{l}\text { Leonordo da Vinci } \\
\text { skiego }\end{array}$ \\
\hline „EURO-IN.NET” & 2016 & $\begin{array}{l}\text { Interreg V-A Republika Cze- } \\
\text { ska-Polska }\end{array}$ \\
\hline
\end{tabular}

Źródło: Opracowano na podstawie dokumentacji EuroInstytutu Polsko-Czesko-Słowackiego.

\section{Działalność edukacyjno-wydawnicza}

W ramach tej działalności organizowane są konferencje naukowe i wydawane opracowania, programy, zeszyty naukowe oraz specjalistyczne poradniki traktujące o problematyce transgranicznej. EuroInstytut współpracuje w tym zakresie z instytucjami branżowymi i naukowymi ${ }^{24}$.

23 Opracowano na podstawie dokumentacji EuroInstytutu.

24 Tamże. 
Tabela 3. Wybrane opracowania i programy dotyczące współpracy transgranicznej na Śląsku Cieszyńskim

\begin{tabular}{|l|c|}
\hline \multicolumn{1}{|c|}{ Nazwa programu lub opracowania } & Data \\
\hline $\begin{array}{l}\text { „Koncepcja powstania międzynarodowego ośrodka doradczo-szkoleniowego EuroInstytutu } \\
\text { PL-CZ” }\end{array}$ & 2009 \\
\hline $\begin{array}{l}\text { Studium Wykonalności EuroInstytutu - etap I. Raport z warsztatów poświęconych pracom } \\
\text { nad stworzeniem międzynarodowego ośrodka doradczo-szkoleniowego -EuroInstytutu w Eu- } \\
\text { roregionie Śląsk Cieszyński” }\end{array}$ & 2010 \\
\hline $\begin{array}{l}\text { „Program Partnerskiej Współpracy Miast Jastrzębie-Zdrój, Karviná, Havířov” - założenia } \\
\text { „Dokumentacja określająca formę współpracy i prowadzenie wspólnych działań w ramach } \\
\text { partnerstwa EuroInstytutu Polsko-Czesko-Słowackiego” } \\
\text { „Przeszkody i potrzeby związane ze współpracą transgraniczną na polsko-czesko-słowackim } \\
\text { pograniczu w kontekście problematyki doradczo-szkoleniowej (analiza)” } \\
\text { „Program Partnerskiej Współpracy Miast Jastrzębie-Zdrój, Karviná, Havírov”- aktualizacja }\end{array}$ & 2013 \\
\hline
\end{tabular}

Źródło: Opracowano na podstawie dokumentacji EuroInstytutu Polsko-Czesko-Słowackiego

Na szczególną uwagę zasługuje współpraca EuroInstytutu z Komisją ds. Stosunków Polsko-Czeskich i Polsko-Słowackich Polskiej Akademii Nauk - Oddział w Katowicach. W ramach tej współpracy od roku 2012 wydawana jest seria „TRANSCARPHATHICA”. Jest to publikacja poświęcona problematyce współpracy transgranicznej oraz relacjom sąsiedzkim łączącym Polaków, Czechów i Słowaków.

W pierwszym tomie, zatytułowanym Pogranicze - Sasiedztwo - Stereotypy. Przypadek polsko-czeskich relacji wraz z francusko-niemieckim case study, zaprezentowano osiem artykułów. Są to rozważania nad problematyką polsko-czeskich pograniczy w perspektywie trwałości, transformacji stereotypów oraz opis przedsięwzięć podejmowanych przez przedstawicieli instytucji animujących życie lokalnych społeczności w rejonie polsko-czeskiego pogranicza ${ }^{25}$.

Tom drugi Pogranicze-Sasiedztwo-Stereotypy. Przypadek polsko-słowackich relacji. Grupy etniczne i etnograficzne na polskim Podkarpaciu przybliża wybrane aspekty polsko-słowackich relacji z perspektywy socjologicznej, etnograficznej i literaturoznawczej. Artykuł autorstwa Zygmunta Kłodnickiego Grupy etniczne i etnograficzne na polskim Podkarpaciu - problem Lachów, ukazuje stereotypy i autostereotypy, dyfuzję kulturową oraz polsko-słowackie korzenie wyrastające ze słowiańskiego dziedzictwa ${ }^{26}$.

25 TRANSCARPATHICA. T. I. Pogranicze - Sąsiedztwo - Stereotypy. Przypadek polsko-czeskich relacji wraz z francusko-niemieckim case study. Red. A. Kasperek, Katowice 2012.

26 TRANSCARPATHICA. T. II. Pogranicze - Sasiedztwo - Stereotypy. Przypa- 


\section{Konferencje naukowe}

W ramach działalności naukowej EuroInstytut organizuje konferencje o wymiarze zarówno transgranicznym, jak i międzynarodowym służące promowaniu współpracy oraz wymianie informacji między przedstawicielami świata nauki i praktyki. W latach 2009-2015 zorganizowano 5 konferencji, 2 fora transgraniczne, 13 szkoleń i 4 warsztaty strategiczne ${ }^{27}$. W badanym okresie odbyło się 11 posiedzeń Rady Programowej ${ }^{28}$.

Jedną z konferencji międzynarodowych zorganizowano 25 listopada 2011 roku w Centrum Konferencyjnym Uniwersytetu Śląskiego w Cieszynie. Konferencja zatytułowana „Współpraca ponad granicami. Nowe wyzwania i możliwości dla Polski i Europy" stanowiła element prac nad studium wykonalności EuroInstytutu. Wzięli w niej udział, obok reprezentantów samorządów członkowskich polskiej i czeskiej strony Euroregionu Śląsk Cieszyński, eksperci, przedstawiciele instytucji doradczo-szkoleniowych, ośrodków naukowych, liderów branżowych, administracji rządowej i samorządowej szczebla regionalnego. Na konferencję zaproszono także polską stronę Euroregionu Silesia.

Na uwagę zasługuje spotkanie, które miało miejsce w Katowicach w dniach 6-7 listopada 2015 roku, kiedy to odbyło się posiedzenie Konferencji Rektorów Uniwersytetów Śląskich mające formułę forum polsko-czeskiej współpracy naukowej i edukacyjnej, zrzeszające Uniwersytet Wrocławski, Uniwersytet Opolski, Uniwersytet Śląski w Katowicach, Uniwersytet Ekonomiczny w Katowicach, Uniwersytet Śląski w Opawie i Uniwersytet Ostrawski ${ }^{29}$.

dek polsko-stowackich relacji. Grupy etniczne i etnograficzne na polskim Podkarpaciu. Red. A. Kasperek, Cieszyn - Katowice 2013.

27 A. Nowak, M. Olszewski, B. Kasperek: Strefa Schengen i inne możliwości rozwoju wspótpracy transgranicznej w Euroregionie Ślask Cieszyński. Raport z konferencji tematycznych zrealizowanych 26 i 27 października 2009 roku z Jaworzu i Jastrzębiu Zdroju, Cieszyn 2010, Dokumentacja EuroInstytutu Polsko-Czesko-Słowackiego.

28 Jedenaste spotkanie Rady Programowej EuroInstytutu odbyło się 31 marca 2016 roku w siedzibie Stowarzyszenia Rozwoju i Współpracy Regionalnej „Olza” w Cieszynie. Spotkanie, któremu przewodniczył Janusz Pierzyna - wójt Jasienicy i prezes Zarządu Stowarzyszenia „Olza”, było poświęcone między innymi prezentacji projektu, regulaminu Rady Programowej oraz nowych przedsięwzięć EURO-IN.NET i EURO-IN.TOOL jako możliwości rozwoju euroinstytutowego partnerstwa.

29 Tamże. 


\section{Uwagi końcowe}

Przedstawiona w zarysie działalność EuroInstytu Polsko-Czesko-Słowackiego ukazuje, jak ważna jest współpraca transgraniczna między państwami. Analizując dokumenty źródłowe EuroInstytu, można stwierdzić, że głównymi obszarami działalności jest działalność szkoleniowo-doradcza, działalność koncepcyjna, badawcza, edukacyjna i wydawnicza. EuroInstytut pomaga podmiotom z obu części pogranicza w rozwiązywaniu problemów wynikających z różnych systemów polityczno-administracyjnych, strukturalnych, w minimalizowaniu wszelkiego rodzaju barier administracyjnych, społecznych, kulturowych oraz w prowadzeniu działań na rzecz współpracy ponad granicami. Jak podkreśla Bogdan Kasperek - dyrektor Biura Stowarzyszenia Rozwoju i Współpracy Regionalnej „Olza” - „wszystkie działania, które podejmujemy, poddajemy ciągłej ewaluacji. Staramy się, aby EuroInstytut Polsko-Czesko-Słowacki spełniał oczekiwania odbiorców, do których adresujemy nasze działania. Wciąż się uczymy, rozwijamy i doskonalimy".

\section{Bibliografia}

Dokumentacja określająca formę wspótpracy i prowadzenie wspólnych dziatań w ramach partnerstwa EuroInstytutu Polsko-Czesko-Stowackiego. Cieszyn 2015.

EuroInstytuut Polsko-Czesko-Stowacki. bmirw.

Europejska Karta Regionów Granicznych i Transgranicznych - nowelizacja SERG. Gronau 2004, SERG.

Euroregiony na granicach Polski 2007. Wrocław 2007, Główny Urząd Statystyczny we Wrocławiu.

Euroregiony pogranicza polsko-czeskiego, B. Kasperek (red.), Cieszyn 2014. Jasiński Z.: Przemiany w polityce oświatowej $i$ społecznej w kontekście edukacji międzykulturowej. W: T. Lewowicki i E. Ogrodzka-Mazur (red.): $Z$ teorii i praktyki edukacji międzykulturowej. Cieszyn - Warszawa 2006, Uniwersytet Śląski, Wyższa Szkoła Pedagogiczna ZNP w Warszawie.

Nowak A., Olszewski M., Kasperek B.: Strefa Schengen i inne możliwości rozwoju wspótpracy. Oferta szkoleniowa EuroInstytutu Polsko-Czesko-Stowackiego, bmirw.

Nowak A., Olszewski M., Kasperek B.: Strefa Schengen i inne możliwości roz- 
woju wspótpracy transgranicznej w Euroregionie Śląsk Cieszyński. Raport z konferencji tematycznych zrealizowanych 26 i 27 października 2009 roku z Jaworzu i Jastrzebiu-Zdroju, Cieszyn 2010, Dokumentacja EuroInstytutu Polsko-Czesko-Słowackiego.

Olszewki M.: Koncepcja powstania międzynarodowego ośrodka doradczo-szkoleniowego EuroInstytutu PL-CZ. Cieszyn 2009.

Program Partnerskiej Wspótpracy Miast Jastrzębie-Zdrój, Karviná, Havírov. Cieszyn 2013.

Przeszkody i potrzeby zwiazane ze wspótpraca transgraniczna na polsko-czesko-stowackim pograniczu w kontekście problematyki doradczo-szkoleniowej (analiza).

Przyszła wspótpraca terytorialna w Euroregionie Ślask Cieszyński - studium, redakcja i autorzy studium: T. Balcar, B. Kasperek, V. Lastuvka, M. Olszewski, M. Malaka, P. Slovacek, Cieszyn - Cesky Tesin 2015.

Raport $z$ warsztatów poświęconych pracom nad stworzeniem międzynarodowego ośrodka doradczo-szkoleniowego - Euroinstytutu w Euroregionie Ślask Cieszyński, autorzy: M. Olszewski / Stowarzyszenie Rozwoju i Współpracy Regionalnej „Olza” w Cieszynie, B. Kasperek / Stowarzyszenie Rozwoju i Współpracy Regionalnej „Olza” w Cieszynie, A. Olszewska / Stowarzyszenie Rozwoju i Współpracy Regionalnej „Olza” w Cieszynie, A. Lewczuk / Biuro Współpracy Dolnego Renu i Województwa Śląskiego Anne Thevenet / Euro-Institut Kehl Strasbourg, Hynek Böhm / Institut EuroSchola v Třinci, Cieszyn 2010.

Sprawozdania z działalności Stowarzyszenia Rozwoju $i$ Wspótpracy Regionalnej „Olza”.

Statut Stowarzyszenia Rozwoju i Współpracy Regionalnej „Olza” z 16. 04.2003. Studium Wykonalności EuroInstytutu - etap I, Cieszyn 2010.

TRANSCARPATHICA. T. I. Pogranicze - Sasiedztwo - Stereotypy. Przypadek polsko-czeskich relacji wraz z francusko-niemieckim case study. Red. A. Kasperek, Katowice 2012.

TRANSCARPATHICA. T. II. Pogranicze - Sasiedztwo - Stereotypy. Przypadek polsko-słowackich relacji. Grupy etniczne i etnograficzne na polskim Podkarpaciu. Red. A. Kasperek, Cieszyn - Katowice 2013.

www.euro-in.org www.olza.pl/pl/dzialalnosc-statutowa/publikacje 


\title{
The activity of Polish-Czech-Slovak EuroInstitute in the field of transfrontier and intercultural cooperation
}

\begin{abstract}
Summary
In 2009 the Association of Development and Regional Cooperation 'Olza' (PL: Stowarzyszenie Rozwoju i Współpracy Regionalnej 'Olza') together with the Institute EuroSchola from Trzyniec created - on the Polish-Czech-Slovakian borderline the first in Central and Eastern Europe EuroInsitute for transfrontier cooperation. The main areas of activity of Polish-Czech-Slovak EuroInstitute are: training and consulting, expertise and research, along with educational and publishing activity. EuroInstitute cooperates with a variety of educational institutions as well as with training and consulting institutions at home and abroad. What the author intends is to publish "TRANSCARPHATHICA" and organize an international conference devoted to the relations between Poland, the Czech Republic and Slovakia.
\end{abstract}

Key words: Polish-Czech-Slovak EuroInstitute, transfrontier and intercultural cooperation, research and scientific activity, trainings

Translated by Marietta Szymańska 